\title{
Education, Research, and Use of Human-Horticulture Relationships in J apan and Korea
}

Eisuke $M$ atsuo

AdDitional INDEX WORDS. H uman issues in horticulture, horticultural therapy, people-plant interactions, sociohorticulture, human well-being

Summary. Plants and horticulture play an integral role in the cultural heritage of eastern societies. Plants are deemed as important in many ways besides being a source of food and shelter. The present study summarizes information on research and trends in the value and application of horticulture collected from professionals in Asian countries, focusing on the work in human-horticulture relationships in Korea and Japan.

$\mathrm{P}$ lants and horticulture play an integral role in the cultural heritage of eastern societies. Plants are deemed as important in many ways besides being a source of food and shelter. $\mathrm{H}$ orticulture benefits us economically, psychologically, mentally, emotionally, environmentally, socially, and educationally (M atsuo, 1997b). O nly recently has the importance of these less tangible relationships been recognized by many academic horticulturists worldwide. This paper documents some of the formal activities in human-horticulture relationships in Asian countries.

To gather information for this manuscript, the author began by reviewing the address list of the People-Plant Council (Blacksburg, Va.) for members in countries in Asia or Africa. The author then sent questionnaires to people who were members in countries other than Korea or J apan. The questionnaire included three questions: 1) What kind of studies do you think are included in the field of human-horticulture relationships? 2) D o you have any organization or society (local or nationwide) which concerns human-horticulture relationships? 3) D oes any university or college have a course or curriculum that includes human-horticulture relationships? W.K. Sim (D epartment of $\mathrm{H}$ orticultural Science, Korea U niversity, Seoul, Korea) provided the information on Korea. $\mathrm{H}$ e has been active in this field for a number of years (Sim, 1997; Sim and Kwack, 1995). This author ( $M$ atsuo) provided the information covering events in J apan.

Bioresource and Bioenvironmental Sciences, Graduate School, Kyushu U niversity, Japan 6-10-1, H akozaki, Fukuoka-shi 812-8581, Japan.

The cost of publishing this paper was defrayed in part by the payment of page charges. U nder postal regulations, this paper therefore must be hereby marked advertisement solely to indicate this fact. 
Reviewing the membership list for the People-Plant Council showed that Asian and African members were located in the following 11 countries: $\mathrm{H}$ ong Kong, India, Indonesia, Iran, I srael, J apan, Korea, Pakistan, People's Republic of China, Saudi Arabia, and South Africa. Thisindicatesthat interest in human-horticulture relationshipsexists in many countries. In response to the questionnaire, the author only received three responses, one each from $\mathrm{H}$ ong Kong, India, and Pakistan. They mentioned a variety of topics that they believed to be included in studies on human-horticulturerelationships(Table $1)$. This list shows that these respondents have similar ideas to others throughout the world about what is generally included under this terminology (Lewis, 1976; M atsuo, 1996; $M$ atsuo and Relf, 1995). The response from Pakistan also noted that lectures on horticultural therapy aregiven there. The lack of more specific responses to this questionnaire could mean that the study of human-horticulture relationships is still in its infancy in many countries, as it was in the $U$ nited States and in Japan in the 1970s. This idea is supported by the lack of published work from researchers in these countries. $C$ harles $L$ ewis recounts the early beginning of this field in the $U$ nited States, stating that in 1972, "I had no ideahow difficult it might befor academic professionals to accept a different way of seeing horticulture" (Lewis, 1994). H e noted that it took two decades for the idea to be morewidely accepted among horticulturists in the U nited States.

\section{Korea}

In Korea, horticultural therapy is becoming popular (Sim, 1997), and plant symbolism has been studied from the human-horticulture relationship point of view (Sim and K wack, 1995). B.H. Kwack, Korea U niversity, introduced horticultural therapy in South Korea at the beginning of the 1980s through lectures and publications. In 1991, H yosung Women's U niversity began offering the course Therapeutic $\mathrm{H}$ orticultureto undergraduatestudents in the D epartment of Floriculture. In 1993, Korea U niversity offered the course Socio-horticultural Implementation to graduate students in the Department of H orticultural Science(Sim, 1997).

At present, Chonnam $\mathrm{N}$ ational U niversity (for graduate students),
Konkuk U niversity (for graduate students), and Ansung $\mathrm{N}$ ational Technical U niversity (for undergraduatestudents) have courses related to horticultural therapy. $\mathrm{H}$ orticultural therapy has been implemented at hospitals, rehabilitation centers, and special education schools. In N ovember 1997, a study group on horticultural therapy was organized. Other special activities related to human-horticulture relationships include special lectures on sociohorticulture sponsored by the Korean Society for $\mathrm{H}$ orticultural Science in O ctober 1995. The Korean Institute of Plant, People and Environment was founded in February 1998 and held an international symposium "Plant and People Interactions in $\mathrm{H}$ uman $\mathrm{H}$ ealth and the Q uality of Life" in May 1998. Such activities show thathuman-horticulture relationships are gaining wide acceptance in Korea.

\section{J apan}

ECONOMICAL PRODUCTION OF FOOD AND FLOWERS. After World War II, the Japanese people were eager to produce their own food. In horticulture, fruit and vegetable production was the main objective. Since the 1960s, flower production has been promoted, but only for economic gain. In other words, the human aspects of horticulture were, at best, ignored for a long time, and, at worst, rejected in favor of traditional academic topics related to horticultural plants, horticultural production, and postharvest storage of horticultural crops.

Japanese horticulturists typically had hesitated to respond to the needs of amateur horticulture or home horticulture, which concern the human aspects of horticulture, because it did not relate to commercial production. They held such opinionsin spite of the fact that, for example, 900,000 copies of the TV text "Shumi-no-engei (H obby gardening)" have been on monthly sale since 1984 (M atsuo, 1995a).

Therehavebeen veryfew presentations on amateur horticulture, home horticulture, or cultural aspects of horticulture at meetings of the Japanese Societyfor H orticultural Science(J SH S) (M atsuo, 1996). Such topics were inclined to be disregarded or criticized as "... not research projects in the field of horticulture." The author himself was criticized when he made presentations on regional appellations of the genus A lliumL. plants(M atsuo, 1974, 1975), home gardening and allotments (M atsuo, 1978a, 1978b), flower use at tombs (M atsuo, 1979), horticultural information on TV and radio ( $M$ atsuo, 1982a), and more. The manuscripts on these topics were routinely rejected by horticultural journals in Japan. Such attitudesof] apanesehorticulturistscame into the open during a presentation on the control of flower direction in $\mathrm{N}$ arcissus L. in 1982 (H ara, 1982, 1983; Kosugi, 1983). $\mathrm{H}$ ara was directly criticized, being told that hisresearch project should not be done at a public research station. This situation may be the case now in most Asian and African countries.

$\mathrm{N}$ ot surprisingly, topics related to human-horticulture relationships such as extension, environments, education, culture, etc., havebeen veryfew in JSH S meetings.

Attention to human aspects of HORTICULTURE. The status of agriculture in J apan changed at the end of 1980s. This resulted in agriculturists and horticulturists becoming interested in establishing allotments in populated areas (similar to community garden plots in the U nited States) and in beautifying rural areasfor farmersto liveand work in pleasurablesurroundings. Thesechanges suggest that people have begun to recognize the role of agriculture and horticulturein human well-being and social development.

O neexampleof thisstriking change in the attitudes of horticulturists toward noncommercial horticulturewasshown by the decision of J SH S in 1990 to use "TheB eautification of $H$ uman $L$ ife and I tsEnvironment through $\mathrm{H}$ orticultural Science" asthemotto of the 24th I nternational $\mathrm{H}$ orticultural Congress $(\mathrm{IHC}$ ) of the International Society for $\mathrm{H}$ orticultural Science held in Kyoto, Japan. This decision led to the organization of a symposium on " $\mathrm{H}$ orticulture in $\mathrm{H} \mathrm{u}$ man Life, Culture, and Environment" ( $M$ atsuo and Relf, 1995). This was very successful and might be regarded as the first international symposium on human-horticulture relationships held outside of the $U$ nited States.

The symposium on " $\mathrm{H}$ orticulture in $\mathrm{H}$ uman Life, Culture, and Environment" at the 24th IHC resulted in increasing horticulturists' interests in human-horticulture relationshipsin Japan and worldwide. The number of topics related to human-horticulture relationships at the meetings of JSH S increased. The number of participants 
T able 1. T opics mentioned by professionals in H ong K ong, I ndia, and Pakistan as included in studies on human-horticulture relationships.

\section{Topic}

A esthetic relationships

Benefits of community gardening

$D$ iseases through plant reaction

Economic and income generation

$\mathrm{H}$ orticulture for disabled and mentally disturbed people

$\mathrm{H}$ orticulture for health-Exercises

$\mathrm{H}$ uman behavior through reaction to plant species

Learning-Science/ art

$\mathrm{N}$ utritional as a protective food

Pollution control and ecological balance

Positive and negative effect of human beings on growth, yield and quality of horticultural crops

Possibility of the relationship for peaceful coexistence

Religious

Significance of horticulture-human interaction to the industry

Sociocultural relationships

Therapeutic benefits of horticulture

Therapeutic uses by establishing the $\mathrm{H}$ ortoriums

who attended theJ SH S workshop, "L ife and $\mathrm{H}$ orticulture," increased markedly over the previous workshop. People's interests in horticultural therapy increased greatly. In 1993, the U niversity of Reading, U.K., began teaching a course in social horticulture for undergraduate students. A special lecture on thesocio-horticultural matterswasheld at the fall meeting of the Korean Society for H orticultural Sciencein 1995. ISH S opened the first symposium on horticultural therapy in Fall 1997. Six Japanese horticulturists participated in the I nternational Symposium People-Plant Council (Sydney) in July 1998.

The increased activities in humanhorticulture relationships in J apan were paralleled by the creation of courses on human-horticulture relationships at universities (M atsuo, 1996). For example, $\mathrm{H}$ orticulture in Life was first taught in 1988 and $\mathrm{H}$ orticulture and Culture in 1990 at Keisen Women's College. In 1991, N ational Kagoshima U niversity began teaching Sociohorticulture. In 1992, Introductory H ome $\mathrm{H}$ orticulture was introduced at Mukogawa Women's U niversity. In 1995, T okyo U niversity of Agriculture created courses in U rban H orticulture and $\mathrm{H}$ orticulture in $\mathrm{L}$ ife. The $\mathrm{N}$ ational Kyushu U niversity offered Socio-horticulture in the same year. In the following year, Keisen Women's College began teaching $\mathrm{H}$ orticulture and Culture at Large.

These processes in Japan are very similar to the development of human horticulture relationships in the U nited
States. At the beginning of 1970 s, the horticulturist, Charles Lewis, who recentlypublished Green $\mathrm{N}$ ature $\mathrm{H}$ uman $N$ ature (Lewis, 1996), noticed the significance of plants on human life, and appealed to horticulturists to examine the area (Lewis, 1976). H e was completely neglected by academic horticulturists. Disappointed by this reaction from his colleagues, he began working actively with specialists in other fields such as psychology, landscaping, and community development. After the 1990 symposium "The Role of $\mathrm{H}$ orticulture in $\mathrm{H}$ uman Well-Being and Social Development" was held, his thoughts and works, along with those of other early proponents of this field, began to receive increased recognition from horticulturists (L ewis, 1994). The author dares to feel that pioneers in any field are always solitary.

Sociohorticulture, or the study of human-horticulture relationships, encompasses a vast array of disciplines, extending from the natural sciences to the social sciences. This allows many approaches to be available for researchers. Research in Japan has resulted in publications by horticulturists on the appellation of A llium plants in different regions (M atsuo, 1982b), consumers' tastein flowers(I manishi and Yonezawa, 1990), flower dedication at tombs (M atsuo, 1992), allotment gardens for children, elderly and impaired people (Konoshima, 1992;, 1998), plant use on station platforms (M atsuo, 1995b), use of horticulture in welfare institutionsand hospitals(M atsuo etal., 1997), and people's physiological responses to flowers (Yamane et al., 1998), among others.

Development of horticultural THERAPY IN J APAN. H orticultural therapy isone example of an applied aspect from the benefits of human-horticultural relationships. I ts objectives include helping people with any impairment, disability, or handicap. H orticultural therapy is in fashion now in Japan, not only among horticulturists, but among ordinary people as well.

$\mathrm{H}$ orticultural therapy was first introduced in Japan in a horticultural magazine in 1982 (Kyoto-daigaku, 1982). It was given little attention by either horticulturists or landscape architects. H orticultural therapy was reintroduced through publications after 1991 (M atsuo, 1991a, 1991b). In 1992, a J apanesestudent in horticultural therapy, M. Sawada, returned after 2 years' horticultural therapy training in theU nited States and began her horticultural therapy work at a welfare institution. In 1993, D iane R elf, Virginia Polytechnic Institute and State U niversity, was invited to lecture at Kagoshima U niversity, and she spoke in Tokyo on horticultural therapy. Thiswasthefirst introduction of horticultural therapy into J apan by an international horticultural therapy specialist.

D uring 1993 and 1994, eight symposia, lectures or workshops by international horticultural therapy professionals were conducted ( $M$ atsuo and Fujiki, 1996). These events were followed by many lectures and workshops in horticultural therapy with Japanese participants in the following years ( $M$ atsuo and M iyajima, 1998). Study groups on horticultural therapy were organized to hold meetings, lectures, discussions, symposia, and workshops for their own enlightenment and to extend horticultural therapy. Such eventsincreased explosively after 1995 (M atsuo and M iyajima, 1998). H ospitals and welfare institutions also began to try horticultural therapy.

Landscape architects comprised many of the people with interests in horticultural therapy when it was first becoming known in) apan ( $M$ atsuo and Fujiki, 1996), but recently, interest among horticulturistsand peoplein hospitals and welfare institutions isincreasing. T wo colleges began offering horticultural therapy courses for students in 1996 and one collegein 1998, and after 1996, somestudy groupsopened short- 
term training courses for horticultural therapists.

This explosive expansion of interest in horticultural therapy has revealed some problems to be solved. For example, 1) there are different understandings of the concepts of horticultural therapy, 2) many horticultural therapy study groups have been organized, and 3) these groups are teaching and developing horticultural therapyand conducting their works by themselves. This situation has led to confusion, for example, regarding what horticultural therapy actually is. In response to this situation, the author proposed the following definition of horticultural therapy (M atsuo, 1997a, 1998b); horticultural therapy is a procedure whereby a horticultural therapist, with professional skills, understands the nature and condition or symptoms of clients, who need any medical or welfare involvement, and uses horticulture to improve their mental or physical conditions or symptoms, recording the procedureand evaluating the results, followed by choosing the next procedure.

The basic idea of horticultural therapy is to utilize the benefits of horticulture for people with any impairment, disability, or handicap to improve their physical or mental condition. It includes cure, care, rehabilitation, promoting physical or mental growth, and enhancing quality of life. That is, horticultural therapy refers to horticultural activities that are done by people who cannotenjoy them or participatein them by themselves without the help or support of professionals. Thesebenefitsfrom horticulture are used not only for these people, but also for ordinary people. In other words, all human beingscan benefit through horticulture, and this benefit can be referred to as horticultural well-being (M atsuo, 1998a).

\section{Conclusion}

People'sinterestsin human-horticulture relationships appear to be expanding in various countries in Asia. The research and interests are quite strong in Korea and J apan. Among the many directions of human-horticulture relationships, horticultural therapy, a practical application of thefield, receives the most attention. Considering horticulture's involvement in our daily lives, we should pay much more attention to the total role of horticulture in life. $\mathrm{H}$ orticulture helps us to live as human beings, to inherit our culture, and to study how to manage the green on this small planet called earth.

\section{Literature cited}

H ara, S. 1982. Kappu-zaki suisen no hanamuki wo seigyo suru kenkyu. 1982 Fall Abstr. M eet. J pn. Soc. H ort. Sci. p. 336-337.

$\mathrm{H}$ ara, S. 1983. Fummuko-Shuki engei gakkai kaki-bukai de okotta hatsugen. Agr. Hort. 58(1):36 .

Kosugi. K. 1983. Fummuko-H arashi no goiken ni taisuru watakushi no iken. Agr. Hort. 58(2):296.

I manishi, $\mathrm{H}$. and F. Yonezawa. 1990. $\mathrm{H}$ ana to hito to no kakawari. Shin-kaki 146:66-71.

Konoshima, H. 1992. H orticulture in education (2) (inJ apanese). J pn. J. Agr. E duc. 23(1):18.

Konoshima, H . 1998. Cosmos garden project of horticultural activities at 'Gull' (J apan). Abst. Intl. People-Plant Symp. (Sydney). p. 20.

Kyoto-daigaku Sosai-kaki Kenkyushitsu. 1982. Engei wo tooshiteno chiryo to rihabilitation. Shin-kaki 113:28-29.

Lewis, C.A. 1976. People/ plant interaction: $\mathrm{H}$ uman perspectivesin horticulture. $\mathrm{H}$ ortScience 11:4-5.

Lewis, C.A. 1994. People-plant relationshipsPast and future, p. 13-25. In: M. Francis, P. Lindsey, and J.S. Rice (eds.). The healing dimension of people-plant relations: Proc. Res. Symp., U niv. C alif., D avis.

Lewis, C.A. 1996. Green nature/ human nature: The meaning of plants in our lives. U niv. III. Press, U rbana.

M atsuo, E. 1974. Wakegi oyobi sono kin-en negirui ni kansuru kenkyu-Kyushu chiho ni okeru negirui no shikibetsu to kosho. Proc. Autumn M eet. J. Soc. H ort. Sci. p. 190-191.

M atsuo, E. 1975. Wakegi oyobi sono kin-en negirui bi kansuru kenkyu-N ainsei shoto $\mathrm{ni}$ okeru negirui sakumotsu no kosho. Proc. Spring M eet. JSH S, p. 126-127.

M atsuo, E. 1978a. Katei engei ni kansuru kenkyu-I dea hachi ni tuite. Proc. Spring M eet. J. Soc. H ort. Sci. p. 422-423.

Matsuo, E. 1978b. Katei engei no kansuru kenkyu-Shimin noen ni tuite. Proc. Autumn M eet. J. Soc. H ort. Sci. p. 184-185.

Matsuo, E. 1979. Amami-oshima ni okeru hakabana ni tuite. Proc. Spring M eet. J. Soc. H ort. Sci. p. 248-249.

$M$ atsuo, E. 1982a. Katei engei no kansuru kenkyu (3). TV, radio ni yoru engei joho. Proc. Autumn M eet. J. Soc. H ort. Sci. p. 334-335.

M atsuo, E. 1982b. Traditional differentiation and appellation of the native A llium vegetables in Amami-oshimal sland, Kagoshima Prefecture (in J apanese). G eograph. Rev. J apan 55(3):151164.
M atsuo, E. 1991a. H ort-therapy 1 (in Japanese). Green joho 12(5):50-51.

M atsuo, E. 1991b. H ort-therapy 2 (in Japanese). Green joho 12(6):42-43.

M atsuo, E. 1992. Cut flower usage for ancestral tombs in Kagoshima, Japan. H ortT echnology 2(2):236-238.

$M$ atsuo, E. 1995a. Amateur engei no sengo 50nen wo miru, p. 289-296, 333-335. In: Y. T sukamoto (ed.). Engei no seiiki 1. $\mathrm{H}$ ana wo tsukuru. Yasaka-shobo, Tokyo.

M atsuo, E. 1995b. What does the plant use on the station platform give an account of? Acta H ort. 391:311-318.

M atsuo, E. 1996. Sociohorticulture : A new field of horticulture and its present status in Europe, the U.S.A. and Japan. J. Korea Soc. H ort. Sci. 37(1):171-185.

M atsuo, E. 1997a. Engei-ryoho ni kakawaru samazamana kotoba 5. Green joho 18(1):71.

M atsuo, E. 1997b. Kurashi to noko-shimin no engei wo kangaeru (1). Agr. H ort. 72(1):9-14.

M atsuo, E. 1998a. What is horticultural wellbeing? Abstr. Intl. People-Plant Sym. (Sydney), p. 21.

M atsuo, E. 1998b. Exploring horticultural therapy-L ooking for healing and humanity (in Japanese). Green J oho, N agoya . p. 257.

M atsuo, E. and Y. Fujiki. 1996. Therapeutic use of horticulture in Japan, p. 118-122. In: P. Williams and J. M. Zajicek (eds.). People-plant interactions in urban areas: Proc. Res. Educ. Symp., Texas A\& M U niv., College Station.

M atsuo, E. , Y. Fujiki, and K. Fujiwara. 1997. Research survey on the therapeutic use of horticulture in welfare institutions and psychiatric hospitals in Fukuoka Prefecture, J apan (in J apanese). Sci. Bul. Fac. Agr. Kyushu U niv. 52(1/ 2):11-20.

M atsuo, E. and I. M iyajima. 1998. U p-to-date trend of horticultural therapy in Japan-An attempt to redefine horticulture in horticultural therapy and place horticultural therapy in relation to other therapies. J. Korean Inst. Plant, People and Environ. 1(1):22-33.

M atsuo, E. and P.D. Relf (eds.). 1995. H orticulture in human life, culture, and environment. Acta H ort. 391:1-334.

Sim, W.K. 1997. Human in horticulture/ People-plant interaction in South Korea. p. 6. D oc. M eet. Intl. Res. H uman I ssues in H orticulture, O ctober 1997, Va. Polytech. Inst. State U niv., Blacksburg.

Sim, W.K. and B.H . Kwack. 1995. Psychological effects of ornamental plants on mental health in Korea. Acta H ort. 391:261-264.

Yamane, K., S. Fukaya, N . Fujishige, K. Yoshino, and M. Katagiri. 1998. Effects of cut flowers on physiological and psychological parameters of human being under stress. Abst. Intl. PeoplePlant Symp. (Sydney). p. 45. 